\title{
PENGARUH KELAS IBU HAMIL TERHADAP PENGETAHUAN DAN SIKAP IBU HAMIL TENTANG INISIASI MENYUSU DINI
}

\author{
Rully Fatriani \\ Akademi Kebidanan Panca Bhakti Bandar Lampung \\ Email: syahidahrully@gmail.com
}

\begin{abstract}
ABSTRAK
Kelas ibu hamil adalah sarana belajar bersama bagi ibu hamil untuk meningkatkan pengetahuan, mengubah sikap dan tindakan ibu. Salah satu materi kelas ibu hamil adalah Inisiasi Menyusu Dini (IMD). Penelitian bertujuan untuk mengetahui pengaruh kelas ibu hamil terhadap pengetahuan dan sikap ibu hamil tentang IMD. Jenis penelitian adalah quasi experimental dengan desain control group pretest-posttest terhadap 52 ibu hamil yang terbagi dua kelompok yaitu mengikuti kelas ibu hamil dan tidak mengikuti kelas ibu hamil dengan menggunakan simple random sampling. Wawancara dilakukan untuk mengukur pengetahuan dan sikap ibu hamil tentang IMD. Data dianalisis menggunakan uji chi-square. Hasil penelitian yaitu terdapat peningkatan pengetahuan ibu hamil tentang IMD dengan kategori baik dari 30,8\% menjadi $100 \%$ setelah mengikuti kelas ibu hamil. Terdapat pengaruh kelas ibu hamil terhadap perubahan sikap ibu hamil tentang IMD (nilai $\mathrm{p}=0,034$ ). Kesimpulan penelitian yaitu terdapat pengaruh kelas ibu hamil terhadap pengetahuan dan sikap ibu hamil dalam pelaksanaan IMD. Kepada bidan diharapkan mengoptimalkan pelaksanaan kelas ibu hamil untuk meningkatkan keberhasilan IMD. Pemegang kebijakan diharapkan meningkatkan perhatian terhadap pelaksanaan kelas ibu hamil di wilayah kerja dengan cakupan IMD rendah.
\end{abstract}

Kata kunci: Kelas Ibu Hamil, Pengetahuan, Sikap, Inisiasi Menyusu Dini

\begin{abstract}
The antenatal class is cooperative learning for pregnant women to increase knowledge, change attitude and practice. One of antenatal class material is early breastfeeding initiation. This research aims to know antenatal class effect on pregnant women knowledge and attitude about early breastfeeding initiation.This type of quasi experimental research design with control group pretest-posttest was used towards 52 pregnant women divided into two groups; attending antenatal class and not attending antenatal class using simple random sampling. Interview was conducted to measure knowledge and attitude about early breastfeeding initiation, mother practice was observed during delivery. Data analysis using chi-square test. The result showed that mothers with good knowledge were increasing from 30,8\% to $100 \%$ after participating in antenatal class. The antenatal class significantly changed attitude about early breastfeeding initiation ( $p$ value $=0,034$ ). The antenatal class was found to be effective in changing maternal knowledge and attitude about early breastfeeding initiation. Midwives are recommended to optimize antenatal class performance to increase early breastfeeding initiation rate. Policy holder also expected to pay attention towards antenatal class implementation in working region with low rate of early breastfeeding initiation
\end{abstract}

Keywords: Antenatal Class, Knowledge, Attitude, Early Breastfeeding Initiation 


\section{PENDAHULUAN}

Penurunan Angka Kematian Ibu (AKI) dan Angka Kematian Bayi (AKB) hingga saat ini masih merupakan isu prioritas dalam program pembangunan kesehatan di Indonesia. Salah satu upaya yang dilakukan yaitu melalui pelaksanaan kelas ibu hamil. Program ini merupakan bagian dari pembinaan kesehatan ibu dan reproduksi dalam Rencana Strategis Kementerian Kesehatan 2015 - 2019. Kelas ibu hamil adalah sarana belajar bersama tentang kesehatan bagi ibu hamil dalam bentuk tatap muka secara berkelompok. Kelas ibu hamil bertujuan untuk mengubah perilaku ibu hamil, termasuk di dalam tujuan tersebut adalah mengubah pengetahuan dan sikap ibu tentang Inisiasi Menyusu Dini (IMD) (Kemenkes, 2014).

IMD adalah upaya memberikan kesempatan kepada bayi untuk menyusu dalam waktu satu jam setelah lahir dengan cara kontak kulit dengan kulit antara ibu dan bayinya. IMD merupakan rekomendasi dari WHO secara global (WHO, 2017). Manfaat tentang IMD telah banyak dilaporkan yaitu dapat menyelamatkan nyawa bayi. Kontak kulit dengan kulit antara ibu dan bayi dapat mencegah bayi dari hipotermia, memperpendek durasi persalinan kala III, memicu produksi ASI dan mengurangi risiko perdarahan ibu postpartum (Acharya dan Khanal, 2015).
Cakupan IMD di Provinsi Sumatera Barat pada Tahun 2016 yaitu sebesar 44,8 \% dan secara nasional hanya sebesar 42,7 \%. Pencapaian tersebut masih berada di bawah pencapaian IMD secara global yaitu sebesar $45 \%$ (Kemenkes, 2016). Rerata cakupan IMD di Kota Padang pada periode 2015 - 2016 yaitu sebesar 91,78\%. Akan tetapi, dari 22 wilayah kerja Dinas Kesehatan Kota Padang terdapat beberapa wilayah kerja dengan rerata cakupan IMD di bawah rerata cakupan IMD Kota Padang yaitu Puskesmas Anak Air (86,80 \%), Puskesmas Belimbing (79,78 \%), Puskesmas Ambacang (85,52 \%), Puskesmas Andalas $(88,20 \%)$ dan Puskesmas Seberang Padang (66,65 \%) (Dinkes Kota Padang, 2017).

Pengetahuan rendah dan sikap negatif ibu hamil adalah faktor penghambat dalam pelaksanaan IMD (Atyeo et al, 2017; Hailemariam et al, 2015; Syam dan Amiruddin, 2015). Pengetahuan dan sikap ibu sangat berperan penting dalam keberhasilan menyusui (Caine et al, 2012). Pengetahuan merupakan domain yang sangat penting dalam membentuk sikap dan tindakan (Glanz et al, 2008). Oleh karena itu, strategi untuk

mencapai keberhasilan IMD adalah melakukan intervensi perubahan perilaku melalui edukasi IMD terhadap ibu hamil (Acharya dan Khanal, 2015). 
Metode belajar bersama memiliki hubungan positif terhadap kinerja peserta belajar di dalam kelas, meningkatnya motivasi serta penyerapan materi secara lebih baik (Adams, 2013). Peserta kelas ibu hamil dalam jumlah kecil akan memudahkan peserta untuk lebih fokus dan mendiskusikan perasaan mereka (Svensson et al, 2008).

Keberhasilan pelaksanaan IMD ditentukan oleh adanya edukasi dan motivasi IMD yang diberikan bidan kepada ibu sejak masa kehamilannya (Hamzah et al, 2017). Penelitian sebelumnya menjelaskan bahwa terdapat hubungan bermakna antara pengetahuan yang baik, sikap positif yang melahirkan intensi yang kuat dan tindakan keberhasilan dalam menyusui (Newby et al, 2014).

Berdasarkan uraian di atas dan mengingat pentingnya memberikan informasi kepada pemegang kebijakan tentang kelas ibu hamil berkaitan dengan pelaksanaan IMD maka penulis tertarik untuk melakukan penelitian lebih lanjut mengenai pengaruh kelas ibu hamil terhadap pengetahuan dan sikap ibu hamil tentang Inisiasi Menyusu Dini.

\section{METODOLOGI}

Jenis penelitian ini adalah quasi experimental dengan desain control group pretest-posttest. Penelitian ini dilakukan di wilayah kerja
Puskesmas Anak Air, Puskesmas Belimbing, Puskesmas Andalas, Puskesmas Ambacang dan Puskesmas Seberang Padang pada Bulan Mei - Oktober 2017.

Populasi dalam penelitian ini adalah seluruh ibu hamil aterm yang melakukan kontrol ANC, memenuhi kriteria inklusi dan eksklusi. Penarikan sampel menggunakan simple random sampling yaitu sebanyak $52 \mathrm{ibu}$ hamil yang terbagi dua kelompok yaitu mengikuti kelas ibu hamil dan tidak mengikuti kelas ibu hamil.

Wawancara dilakukan untuk mengukur pengetahuan dan sikap ibu hamil tentang IMD sebelum dan sesudah intervensi, kemudian dianalisis menggunakan uji chi-square.

\section{HASIL PENELITIAN}

\section{Pengetahuan Ibu Hamil tentang IMD}

Tabel 1. Distribusi Frekuensi Tingkat Pengetahuan Ibu tentang IMD Pretest dan Posttest pada Kelompok Perlakuan dan Kelompok Kontrol

\begin{tabular}{lcccccccc}
\hline & \multicolumn{3}{c}{ Kelompok Perlakuan } & \multicolumn{3}{c}{ Kelompok Kontrol } \\
\cline { 2 - 9 } $\begin{array}{c}\text { Pengetahuan } \\
\text { Ibu Hamil }\end{array}$ & \multicolumn{2}{c}{ Pretest } & Posttest & Pretest & \multicolumn{2}{c}{ Posttest } \\
\cline { 2 - 9 } & $\mathrm{f}$ & $\%$ & $\mathrm{f}$ & $\%$ & $\mathrm{f}$ & $\%$ & $\mathrm{f}$ & $\%$ \\
\hline Baik & 8 & 30,8 & 26 & 100 & 7 & 26,9 & 6 & 23,1 \\
Cukup & 8 & 30,8 & 0 & 0 & 9 & 34,6 & 8 & 30,8 \\
Kurang & 10 & 38,5 & 0 & 0 & 10 & 38,5 & 12 & 46,2 \\
\hline Total & 26 & 100 & 26 & 100 & 26 & 100 & 26 & 100 \\
\hline
\end{tabular}


Berdasarkan tabel 1 diketahui bahwa pada saat pretest lebih dari sepertiga responden kelompok perlakuan dan kelompok kontrol mempunyai pengetahuan tentang IMD dengan kategori kurang (38,5\%). Pada saat posttest, hampir separuh responden kelompok kontrol mempunyai pengetahuan tentang IMD dengan kategori kurang (46,2\%). Responden kelompok perlakuan pada saat pretest mempunyai pengetahuan dengan kategori baik sebanyak 30,8 \%, kemudian pada saat posttest mempunyai pengetahuan dengan kategori baik sebanyak $100 \%$.

\section{Sikap Ibu Hamil tentang IMD}

Tabel 2. Distribusi Frekuensi Perubahan Sikap Ibu tentang IMD Pretest dan Posttest pada Kelompok Perlakuan dan Kelompok Kontrol

\begin{tabular}{|c|c|c|c|c|c|c|c|c|}
\hline \multirow{3}{*}{$\begin{array}{l}\text { Sikap } \\
\text { Ibu } \\
\text { Hamil }\end{array}$} & \multicolumn{4}{|c|}{ Kelompok Perlakuan } & \multicolumn{4}{|c|}{ Kelompok Kontrol } \\
\hline & \multicolumn{2}{|c|}{ Pretest } & \multicolumn{2}{|c|}{ Posttest } & \multicolumn{2}{|c|}{ Pretest } & \multicolumn{2}{|c|}{ Posttest } \\
\hline & $\mathrm{f}$ & $\%$ & $\mathrm{f}$ & $\%$ & $\mathrm{f}$ & $\%$ & $\mathrm{f}$ & $\%$ \\
\hline Positif & 14 & 53,8 & 22 & 84,6 & 16 & 61,5 & 14 & 53,8 \\
\hline Negatif & 12 & 46,2 & 4 & 15,4 & 10 & 38,5 & 12 & 46,2 \\
\hline Total & 26 & 100 & 26 & 100 & 26 & 100 & 26 & 100 \\
\hline
\end{tabular}

Berdasarkan tabel 2, pada kelompok perlakuan diketahui responden mempunyai sikap positif pada saat pretest yaitu sebanyak $53,8 \%$, kemudian pada saat posttest menjadi sebanyak 84,6\%. Berbeda dengan kelompok kontrol, pada saat pretest mempunyai sikap positif tentang IMD sebanyak 61,5\%, kemudian pada saat posttest berubah menjadi $53,8 \%$.

\section{Pengaruh Kelas Ibu Hamil Terhadap} Peningkatan Pengetahuan Ibu Hamil tentang IMD

Tabel 3. Tingkat Pengetahuan Ibu Hamil tentang IMD pada Kelompok Kontrol dan Kelompok Perlakuan Sebelum Intervensi

\begin{tabular}{|c|c|c|c|c|c|c|c|c|c|}
\hline \multirow{3}{*}{ Responden } & \multicolumn{6}{|c|}{$\begin{array}{c}\text { Pengetahuan Ibu tentang } \\
\text { IMD } \\
\end{array}$} & \multirow{2}{*}{\multicolumn{2}{|c|}{ Total }} & \multirow{3}{*}{$\begin{array}{c}p \\
\text { Value } \\
\end{array}$} \\
\hline & \multicolumn{2}{|c|}{ Baik } & \multicolumn{2}{|c|}{ Cukup } & \multicolumn{2}{|c|}{ Kurang } & & & \\
\hline & $\mathrm{f}$ & $\%$ & $\mathrm{f}$ & $\%$ & $\mathrm{f}$ & $\%$ & $\mathrm{f}$ & $\%$ & \\
\hline $\begin{array}{l}\text { Mengikuti } \\
\text { KIH }\end{array}$ & 8 & 30,8 & 8 & 30,8 & 10 & 38,5 & 26 & 100 & \\
\hline $\begin{array}{l}\text { Tidak } \\
\text { Mengikuti } \\
\text { KIH }\end{array}$ & 7 & 26,9 & 9 & 34,6 & 10 & 38,5 & 26 & 100 & 0,939 \\
\hline Total & 15 & 28,8 & 17 & 32,7 & 20 & 38,5 & 52 & 100 & \\
\hline
\end{tabular}

Berdasarkan tabel 3. menunjukkan bahwa tidak terdapat perbedaan pengetahuan ibu hamil tentang IMD antara kelompok perlakuan dan kelompok kontrol sebelum diintervensi karena diperoleh nilai $p$ sebesar 0,939 .

Tabel 4. Pengaruh Kelas Ibu hamil terhadap Tingkat Pengetahuan Ibu Hamil tentang IMD Setelah Intervensi

\begin{tabular}{|c|c|c|c|c|c|c|c|c|}
\hline \multirow{3}{*}{ Responden } & \multicolumn{6}{|c|}{ Tingkat Pengetahuan } & \multirow{2}{*}{\multicolumn{2}{|c|}{ Total }} \\
\hline & \multicolumn{2}{|c|}{ Baik } & \multicolumn{2}{|c|}{ Cukup } & \multicolumn{2}{|c|}{ Kurang } & & \\
\hline & $\mathrm{f}$ & $\%$ & $\mathrm{f}$ & $\%$ & $f$ & $\%$ & $\mathrm{f}$ & $\%$ \\
\hline $\begin{array}{l}\text { Mengikuti } \\
\text { KIH }\end{array}$ & 26 & 100 & 0 & 0 & 0 & 0 & 26 & 100 \\
\hline $\begin{array}{l}\text { Tidak } \\
\text { Mengikuti } \\
\text { KIH }\end{array}$ & 6 & 23,1 & 8 & 30,8 & 12 & 46,2 & 26 & 100 \\
\hline Total & 32 & 61,5 & 8 & 15,4 & 12 & 23,1 & 52 & 100 \\
\hline
\end{tabular}


Berdasarkan tabel 4 menunjukkan bahwa semua responden yang mengikuti kelas ibu hamil mempunyai pengetahuan dengan kategori baik (100 \%), sedangkan pada kelompok yang tidak mengikuti kelas ibu hamil diketahui hampir separuh responden mempunyai pengetahuan dengan kategori kurang (46,2 \%). Berdasarkan tabel 4 uji chisquare tidak dapat dilakukan karena ada cell yang bernilai 0 pada kelompok yang mengikuti kelas ibu hamil. Akan tetapi, data pada tabel 3 dan table 4 menunjukkan bahwa terdapat peningkatan pengetahuan responden tentang IMD setelah intervensi. Responden berpengetahuan baik hanya sebanyak 30,8\% sebelum mengikuti kelas ibu hamil, kemudian meningkat menjadi $100 \%$ setelah mengikuti kelas ibu hamil.

\section{Pengaruh Kelas Ibu Hamil Terhadap}

\section{Perubahan Sikap Ibu Hamil tentang IMD}

Tabel 5. Sikap Ibu Hamil tentang IMD pada

Kelompok Kontrol dan Kelompok Perlakuan Sebelum Intervensi

\begin{tabular}{|c|c|c|c|c|c|c|c|}
\hline \multirow{3}{*}{$\begin{array}{c}\text { Respon } \\
\text { den }\end{array}$} & \multicolumn{4}{|c|}{ Sikap Ibu Hamil } & \multirow{2}{*}{\multicolumn{2}{|c|}{ Total }} & \multirow{3}{*}{$\begin{array}{c}p \\
\text { Value }\end{array}$} \\
\hline & \multicolumn{2}{|c|}{ Positif } & \multicolumn{2}{|c|}{ Negatif } & & & \\
\hline & $\mathrm{f}$ & $\%$ & $\mathrm{f}$ & $\%$ & $\mathrm{f}$ & $\%$ & \\
\hline $\begin{array}{l}\text { Mengik } \\
\text { uti KIH }\end{array}$ & 14 & 53,8 & 12 & 46,2 & 26 & 100 & \multirow{2}{*}{0,779} \\
\hline $\begin{array}{l}\text { Tidak } \\
\text { Mengik } \\
\text { uti KIH }\end{array}$ & 16 & 61,5 & 10 & 38,5 & 26 & 100 & \\
\hline Total & 30 & 57,7 & 22 & 42,3 & 52 & 100 & \\
\hline
\end{tabular}

Berdasarkan hasil uji chi-square pada tabel 5 menunjukkan bahwa tidak terdapat perbedaan pengetahuan ibu hamil tentang IMD antara kelompok perlakuan dan kelompok kontrol sebelum intervensi karena diperoleh nilai $p$ sebesar 0,779 .

Tabel 6. Pengaruh Kelas Ibu Hamil terhadap Perubahan Sikap Ibu Hamil tentang IMD Setelah Intervensi

\begin{tabular}{|c|c|c|c|c|c|c|c|}
\hline \multirow{3}{*}{$\begin{array}{l}\text { Respond } \\
\text { en }\end{array}$} & \multicolumn{4}{|c|}{$\begin{array}{c}\text { Sikap Ibu Hamil tentang } \\
\text { IMD }\end{array}$} & \multirow{2}{*}{\multicolumn{2}{|c|}{ Total }} & \multirow{3}{*}{$\begin{array}{l}p \\
\text { Value }\end{array}$} \\
\hline & \multicolumn{2}{|c|}{ Positif } & \multicolumn{2}{|c|}{ Negatif } & & & \\
\hline & $\mathrm{f}$ & $\%$ & $\mathrm{f}$ & $\%$ & $\mathrm{~F}$ & $\%$ & \\
\hline $\begin{array}{l}\text { Mengiku } \\
\text { ti KIH }\end{array}$ & 22 & 84,6 & 4 & 15,4 & 26 & 100 & \\
\hline $\begin{array}{l}\text { Tidak } \\
\text { Mengiku } \\
\text { ti KIH }\end{array}$ & 14 & 53,8 & 12 & 38,5 & 26 & 100 & 0,034 \\
\hline Total & 36 & 69,2 & 16 & 30,8 & 52 & 100 & \\
\hline
\end{tabular}

Berdasarkan tabel 6 menunjukkan adanya pengaruh kelas ibu hamil terhadap sikap ibu hamil tentang IMD karena diperoleh nilai $p$ sebesar 0,034. Hampir semua responden yang telah mengikuti kelas ibu hamil mempunyai sikap positif tentang IMD yaitu sebanyak 84,6 $\%$. Sementara itu, responden yang tidak mengikuti kelas ibu hamil hanya sebanyak $53,8 \%$ yang mempunyai sikap positif tentang IMD.

\section{PEMBAHASAN}

Pengaruh Kelas Ibu Hamil Terhadap

Peningkatan Pengetahuan Ibu Hamil tentang IMD 
Hasil penelitian ini menunjukkan bahwa kelas ibu hamil dapat meningkatkan pengetahuan ibu hamil tentang IMD karena ada peningkatan persentase peserta berpengetahuan baik dari 30,8 \% menjadi 100 $\%$. Berdasarkan data tersebut, ibu hamil yang telah mengikuti kelas ibu hamil seluruhnya menjadi berpengetahuan baik. Pemilihan metode pembelajaran dan alat bantu belajar yang dipakai sangat menentukan keberhasilan dalam upaya peningkatan pengetahuan ibu hamil tentang IMD. Metode dan alat bantu yang tepat akan memudahkan materi diserap dengan baik oleh peserta. Apabila informasi mengenai IMD semakin banyak diserap oleh ibu hamil maka secara otomatis akan meningkatkan pengetahuan ibu hamil tentang IMD.

Metode belajar bersama di dalam kelas ibu hamil adalah metode yang mampu meningkatkan motivasi dan memberikan hasil terbaik dalam pencapaian hasil belajar. Peserta yang lebih cepat menyerap materi akan berperan sebagai 'pendidik rekan sebaya' (peer educator) bagi peserta lain (Svensson et al, 2008). Metode belajar bersama merupakan metode paling efektif apabila dibandingkan dengan metode belajar lainnya, terutama dalam meningkatkan kinerja peserta belajar (Adams, 2013).
Seseorang akan lebih mudah meyakini kebenaran suatu informasi apabila ia mengetahui bahwa informasi tersebut berasal dari narasumber yang dapat dipercayai. Dengan demikian, pengetahuan IMD yang diperoleh dalam kelas ibu hamil adalah sekumpulan informasi IMD yang terjamin akurat karena bersumber dari orang yang ahli atau menguasai bidangnya yaitu bidan. Ibu hamil memerlukan orang yang ahli dalam masalah kehamilan dan persalinan sebagai tempat untuk bertanya dan mendapatkan jawaban yang berkualitas atau akurat (Svensson et al, 2008).

Jumlah peserta di dalam kelas juga sangat menentukan keberhasilan seseorang dalam menyerap materi belajar. Jumlah peserta dalam kelas yang dibatasi maksimal 10 orang dapat membuat peserta lebih fokus (Kemkes, 2014). Peserta kelas ibu hamil dalam jumlah kecil akan memudahkan peserta lebih leluasa untuk mendiskusikan perasaan mereka. Peserta membutuhkan kondisi kelas yang dapat membuat mereka lebih didengarkan dan diperhatikan pada saat proses pembelajaran sedang berlangsung (Svensson et al, 2008).

Hasil penelitian ini sejalan dengan hasil penelitian sebelumnya di Denpasar, Bali dan hasil penelitian di Metro, Lampung yang melaporkan bahwa kelas ibu hamil dapat meningkatkan pengetahuan ibu tentang IMD. Skor pengetahuan ibu tentang IMD pada 
kelompok ibu yang mengikuti kelas ibu hamil ditemukan lebih tinggi dari skor pengetahuan ibu tentang IMD pada kelompok ibu yang tidak mengikuti kelas ibu hamil. Persentase ibu yang berpengetahuan baik setelah terpapar kelas ibu hamil di Metro, Lampung adalah sebesar 58,14 \%. Data penelitian tersebut menunjukkan bahwa pemahaman peserta kelas ibu hamil masih belum optimal karena cara penyampaian materi masih perlu ditingkatkan agar lebih mudah dipahami dan diserap oleh peserta (Wijayanti, 2013; Sumiasih, 2013).

Penelitian ini juga dapat menjelaskan bahwa kombinasi alat bantu belajar menggunakan video diketahui sangat berperan dalam meningkatkan penyerapan materi belajar secara lebih baik apabila dibandingkan dengan metode penyampaian materi IMD yang menggunakan alat bantu standar (lembar balik dan buku KIA). Kelas ibu hamil dengan penayangan video IMD merupakan metode yang tepat untuk menyediakan pengetahuan yang memadai tentang IMD (Kronborg et al, 2012).

\section{Pengaruh Kelas Ibu Hamil Terhadap} Perubahan Sikap Ibu Hamil tentang IMD

Hasil penelitian pada kelompok perlakuan yaitu ibu yang mengikuti kelas ibu hamil menunjukkan adanya perubahan sikap ibu tentang IMD secara signifikan ( $p$ value sebesar 0,034). Sebelum mengikuti kelas ibu hamil, peserta yang memiliki sikap positif tentang IMD hanya sebesar 53,8 \% atau sekitar setengah dari jumlah peserta. Setelah mengikuti kelas ibu hamil, peserta yang memiliki sikap positif tentang IMD meningkat menjadi 84,6 \%, atau dengan kata lain sebagian besar peserta yang telah mengikuti kelas ibu hamil memiliki sikap yang positif tentang IMD.

Kelas ibu hamil dengan kelompok kecil memberikan kesempatan kepada peserta untuk saling menguatkan, berbagi pengalaman dan mencurahkan kecemasannya. Ibu hamil yang telah memiliki sikap positif tentang IMD akan lebih mudah menularkan sikap positif tersebut kepada rekannya dalam suasana tertutup dalam kelompok (Svensson et al, 2008). Interaksi sesama peserta dapat menguatkan kepercayaan diri yang akan berhubungan dengan kuatnya keyakinan ibu hamil terhadap IMD (Kronborg et al, 2012).

Fasilitator kelas ibu hamil berperan dalam meningkatkan pengetahuan ibu tentang IMD. Pengetahuan yang rendah tentang IMD berhubungan dengan keyakinan negatif terhadap IMD (Hailemariam et al, 2015). Adanya peran dari rekan secara bersama-sama memberikan penguatan sikap ibu yakni keyakinan yang benar tentang manfaat IMD. Hal ini memungkinkan ibu memiliki sikap 
yang positif yang lahir dari pengetahuan yang baik, keyakinan kuat dan kepercayaan terhadap dirinya sendiri.

Intervensi melalui edukasi yang dilakukan terhadap ibu hamil berperan dalam mengubah keyakinan negatif dan miskonsepsi tentang menyusui. Materi edukasi IMD yang disampaikan dalam kelas ibu hamil meliputi materi sanggahan tentang mitos-mitos IMD yang berkembang di masyarakat. Keyakinan yang benar terhadap praktik IMD akan melahirkan sikap positif tentang IMD. Paparan informasi yang tepat dari tenaga kesehatan dapat mengubah sikap negatif ibu terhadap IMD menjadi positif (Atyeo et al, 2017).

Hasil penelitian ini sejalan dengan penelitian yang dilaksanakan di Metro, Lampung dan Denpasar, Bali menyatakan bahwa ibu yang memiliki sikap positif tentang IMD pada kelompok yang terpapar kelas ibu hamil lebih tinggi daripada kelompok yang tidak terpapar kelas ibu hamil. (Wijayanti, 2013; Sumiasih, 2013)

Kelas ibu hamil berpengaruh dalam mengubah sikap ibu hamil dari sikap negatif menjadi sikap positif tentang IMD melalui penyampaian sanggahan terhadap keyakinan negatif atau mitos mengenai IMD. Sikap dan keyakinan yang positif terhadap IMD berhubungan dengan lahirnya intensi yang kuat dari ibu hamil untuk melaksanakan IMD. Keyakinan positif tentang menyusui akan berhubungan dengan lahirnya intensi menyusui. Intensi ibu yang tinggi untuk melaksanakan IMD berhubungan dengan tingkat keberhasilannya dalam pelaksanaan IMD (Newby et al, 2014).

Penelitian ini mendukung rekomendasi dari Acharya dan Khanal Tahun 2015 di Nepal yang menyatakan bahwa edukasi IMD dalam kunjungan antenatal adalah strategi yang tepat untuk mewujudkan keberhasilan IMD. Paparan informasi tentang IMD dari bidan melalui kelas ibu hamil dapat meningkatkan keberhasilan dalam pelaksanaan IMD. Peran bidan dalam keberhasilan pelaksanaan IMD tidak hanya pada saat persalinan tetapi dimulai sejak kehamilan (Atyeo et al, 2017).

\section{KESIMPULAN}

Berdasarkan hasil penelitian dapat disimpulkan bahwa:

1. Terdapat peningkatan pengetahuan ibu hamil tentang IMD setelah mengikuti kelas ibu hamil dengan kategori baik dari $30,8 \%$ menjadi $100 \%$.

2. Terdapat pengaruh kelas ibu hamil terhadap perubahan sikap ibu hamil tentang IMD dengan sikap positif dari $53,8 \%$ menjadi $84,6 \%(p=0,0034)$. 
Bidan sebagai pengelola diharapkan mengoptimalkan pelaksanaan kelas ibu hamil untuk meningkatkan keberhasilan IMD.

Pemegang kebijakan diharapkan meningkatkan perhatian terhadap pelaksanaan kelas ibu hamil di wilayah kerja dengan cakupan IMD rendah.

\section{KEPUSTAKAAN}

Acharya, P. \& Khanal, V. (2015). The Effect Of Mother's Educational Status on Early Initiation of Breastfeeding: Further Analysis of Three Consecutive Nepal Demographic and Health Surveys. Public Health. 15:1069.

Adams, AR. (2013). Cooperative Learning Effects on the Classroom. Thesis. Northern Michigan University.

Atyeo, NN. Frank, TD. Vail, EF. Sperduto, WAL. Boyd, DL. (2017). Early Initiation of Breastfeeding Among Maya Mothers in Western Highlands of Guatemala: Practices and Beliefs. Journal of Human Lactation. pp. 1-9. DOI: $10.1177 / 089033416682729$.

Caine, VA. Smith, M. Beasley, Y. Brown, HL. (2012). The Impact of Prenatal Education on Behavioral Changes Toward Breast Feeding and Smoking Cessation in a Healthy Start Population. Journal of The National Medical Association. Vol 104. NOS 5 \& 6. pp. 258-264.

Kementerian Kesehatan RI. (2014). Pedoman Pelaksanaan Kelas Ibu Hamil. Jakarta: Kementerian Kesehatan Republik Indonesia.

Kementerian Kesehatan RI. (2016). Profil Kesehatan Indonesia Tahun 2015. Jakarta: Kementerian Kesehatan Republik Indonesia.

Kronborg, H. Maimburg, RD. Vaeth, M. (2012). Antenatal Training to Improve Breast Feeding: a Randomized Trial. Journal of Midwifery. 28. pp. 784-790.
Dinas Kesehatan KotaPadang. (2017).

Laporan TahunanDinas

Kesehatan Kota Padang Tahun 2016. Padang.

Glanz, K. Rimer, BK. Viswanath, K. (eds.). (2008). Health Behavior and Health Education Theory, Research, and Practice. San Francisco: Jossey-Bass.

Hailemariam, TW. Adeba, E. Sufa, A. (2015). Predictors of Early Breastfeeding Initiation amng Mothers of Children under 24 Months of Age in Rural Part of West Ethiopia. BMC Public Health. 15:1076. DOI: 10.1186/s12889-015-2420-z.

Hamzah, F. Wahyuni, CU. Notobroto, HB. (2017). Factors Affecting Implementation of Early Initiation of Breastfeeding. Dama International Journal of Researchers. Vol 2. Issue 3. pp. 47-49.

HO. (2017). Early initiation of breastfeeding to promote exclusive breastfeeding. Geneva: World Health Organization; (Diakses $15 \quad$ Agustus 2017). <http://www.who.int/elena/ titles/ early breastfeeding/en/>.

Wijayanti, YT. (2013). Pengaruh Kelas Ibu Hamil Terhadap Perilaku Ibu dalam Inisiasi Menyusu Dini di Kota Metro. Jurnal Kesehatan Metro Sai Wawai. Vol VI. No 2.

Newby, R. Brodribb, W. Ware, RS. Davies, PSW. (2014).Infant Feeding Knowledge, Attitudes and Beliefs PredictAntenatal Intention Among First-Time Mothern in Queensland. Breastfeeding Medicine. Vol 9. Number 5. DOI: 10.1089/bfm.2014.0012.

Sumiasih, NN. (2013). Pengaruh Kelas Antenatal Terhadap Peningkatan Pengetahuan, Keterampilan dan Keberhasilan 
Inisiasi Menyusu Dini pada Ibu Bersalin di Wilayah Kerja Puskesmas Dauh Puri Denpasar. Jurnal Skala Husada. Vol 10. No 1. pp. $105-112$.

Svensson, J. Barclay, L. Cooke, M. (2008).

Effective Antenatal Education: Strategies by Expectant and New Parents. The Journal of Perinatal Education. 17(4). pp. 33-42.
Syam, A. Amiruddin, R. (2015). Inhibitor Factors of Early Iniatiayion of Breastfeeding among Mothers in Rural District Bone, South Sulawesi. 